\title{
Large decadal scale changes of polar ozone suggest solar influence
}

\author{
B.-M. Sinnhuber ${ }^{1}$, P. von der Gathen ${ }^{2}$, M. Sinnhuber ${ }^{1}$, M. Rex ${ }^{2}$, G. König-Langlo ${ }^{3}$, and S. J. Oltmans ${ }^{4}$ \\ ${ }^{1}$ Institute of Environmental Physics, University of Bremen, Bremen, Germany \\ ${ }^{2}$ Alfred-Wegener-Institute for Polar and Marine Research, Research Unit Potsdam, Potsdam, Germany \\ ${ }^{3}$ Alfred-Wegener-Institute for Polar and Marine Research, Bremerhaven, Germany \\ ${ }^{4}$ NOAA Climate Monitoring and Diagnostics Laboratory, Boulder, Colorado, USA
}

Received: 25 October 2005 - Published in Atmos. Chem. Phys. Discuss.: 24 November 2005

Revised: 31 March 2006 - Accepted: 3 April 2006 - Published: 29 May 2006

\begin{abstract}
Long-term measurements of polar ozone show an unexpectedly large decadal scale variability in the midstratosphere during winter. Negative ozone anomalies are strongly correlated with the flux of energetic electrons in the radiation belt, which is modulated by the 11-year solar cycle. The magnitude of the observed decadal ozone changes $(\approx 20 \%)$ is much larger than any previously reported solar cycle effect in the atmosphere up to this altitude. The early-winter ozone anomalies subsequently propagate downward into the lower stratosphere and may even influence total ozone and meteorological conditions during spring. These findings suggest a previously unrecognized mechanism by which solar variability impacts on climate through changes in polar ozone.
\end{abstract}

\section{Introduction}

The Arctic stratospheric ozone layer shows considerable inter-annual variability. A better understanding of the processes controlling the inter-annual variability is necessary in order to predict how the ozone layer will evolve in a future climate (World Meteorological Organization, 2003). Solar induced changes in stratospheric ozone are of particular interest as they may provide a link between solar variability and climate (Haigh, 1994; Shindell et al., 1999). Changes in stratospheric ozone as a result of changes in solar UV radiation over the 11-year solar cycle have been well known for a long time. However, previously reported ozone changes over the solar cycle reach only about $4 \%$ with a maximum amplitude at low latitudes in the upper stratosphere $(\approx 45 \mathrm{~km}$ altitude) (Hood, 2004). In addition to variations in the UV flux, solar variability can influence polar stratospheric ozone through precipitation of energetic particles into the

Correspondence to: B.-M. Sinnhuber

(bms@iup.physik.uni-bremen.de) atmosphere at high latitudes. Precipitation of energetic particles during large solar proton events, which occur sporadically predominantly during solar maximum, can reduce polar stratospheric ozone significantly (Jackman et al., 2000; Randall et al., 2005). Similarly, precipitation of energetic electrons from the radiation belts may lead to depletion of mesospheric and stratospheric ozone (Thorne, 1977; Baker et al., 1987; Callis and Lambeth, 1998). The large-scale effects of energetic particle precipitation on stratospheric ozone, however, are still controversial (Callis et al., 2001, 2002; Siskind, 2002).

Here we present observations of stratospheric ozone profiles from ozone sonde measurements at the Arctic station of $\mathrm{Ny}$-Ålesund $\left(79^{\circ} \mathrm{N}, 11^{\circ} \mathrm{E}\right)$ and the two Antarctic stations Neumayer $\left(70^{\circ} \mathrm{S}, 8^{\circ} \mathrm{E}\right)$ and South Pole $\left(90^{\circ} \mathrm{S}\right)$. In order to test to what extent the observed ozone changes can be explained by changes in the meteorological conditions during individual years, we have compared the ozone observations with calculations from a stratospheric chemical transport model (CTM).

\section{Data and model}

\subsection{Ozone sonde measurements}

The ozone sondes used in this analysis are electrochemical concentration cell (ECC) sondes from Science Pump Corporation (SPC), types SPC-5A and SPC-6A. The precision of a single sonde measurement in the altitude range of 20 to $30 \mathrm{~km}$ is estimated as $\pm 8 \%$ (Smit and Straeter, 2004). In order to improve the signal to noise ratio, we have averaged the sonde measurements over three month periods. First, each ozone sonde profile was interpolated on an equidistant potential temperature grid. Then for each potential temperature bin all sondes within a given three month period were averaged without any further weighting. Here we have included ozone

Published by Copernicus GmbH on behalf of the European Geosciences Union. 
(a)
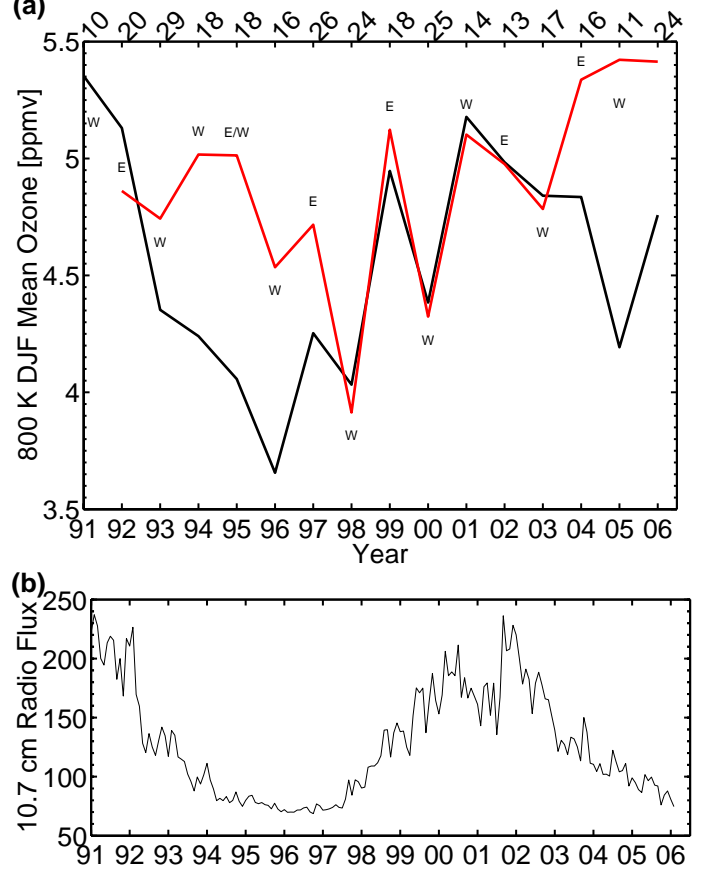

(c)

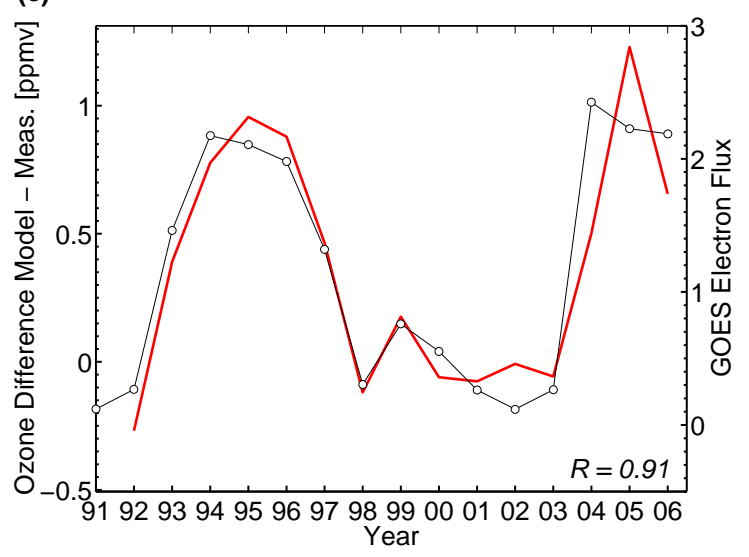

Fig. 1. Measured and modeled December to February (DJF) mean Arctic ozone in the mid-stratosphere at $\mathrm{Ny}$-Ålesund, compared to the solar cycle and the flux of energetic electrons in the outer radiation belt. (a) DJF mean ozone at $800 \mathrm{~K}$ potential temperature ( $\approx 30 \mathrm{~km}$ altitude), from ozone sondes (black line) and model calculations (red line). Numbers at the top of the figure indicate the number of sondes included in each individual DJF period. Letters "W" and "E" indicate westerly and easterly phases, respectively, of the QBO of equatorial zonal mean zonal wind at $50 \mathrm{hPa}$. (b) Monthly mean $10.7 \mathrm{~cm}$ solar radio flux in $10^{-22} \mathrm{Js}^{-1} \mathrm{~m}^{-2} \mathrm{~Hz}^{-1}$. (c) Difference between modeled and measured ozone shown in panel (a) (red line), together with the July to December mean flux of electrons with energies $>2 \mathrm{MeV}$ measured by the GOES satellites at geostationary altitude (black line with symbols). The correlation coefficient between the ozone differences and the electron flux is $R=0.91$. For comparison, the correlation coefficient between the ozone differences and the solar radio flux is $R=-0.72$. sonde observations since 1991 for Ny-Ålesund and South Pole and since 1992 for Neumayer. Before 1991 only very few mid-winter sonde measurements were available. All in total more than 3300 sondes were used in this study.

\subsection{Chemical transport model and meteorological analyses}

Our stratospheric CTM (Sinnhuber et al., 2003) is forced by temperatures and wind fields from analyses of the UK Met Office (Swinbank and O'Neill, 1994). The model uses potential temperature as vertical coordinate; vertical transport is calculated from interactively computed diabatic heating rates. The model has 24 levels between 300 and $3000 \mathrm{~K}$ $\left(\approx 10\right.$ to $55 \mathrm{~km}$ altitude) with a horizontal resolution of $2.5^{\circ}$ by $3.75^{\circ}$. The model calculations presented here use a parameterised ozone chemistry (McLinden et al., 2000) that itself has no inter-annual variability. The model was initialised in October 1991 and integrated until March 2006.

\section{Results and discussion}

3.1 Ozone sonde observations and correlation with electron flux

Figure 1a shows the mean ozone volume mixing ratio (VMR) at Ny-Ålesund during December, January, February (DJF) at the $800 \mathrm{~K}$ isentropic level, corresponding to an altitude of approximately $30 \mathrm{~km}$. A large decadal scale variability is evident, in phase with the solar cycle, with lower ozone VMR during solar minimum and higher ozone VMR during solar maximum. For comparison, Fig. $1 \mathrm{~b}$ shows the $10.7 \mathrm{~cm}$ solar radio flux, a proxy that is well correlated with changes in solar UV radiation. However, the magnitude of the observed decadal scale ozone variations with about $20 \%$ is much larger than what could be explained by changes in solar UV radiation alone (Hood, 2004). In addition to the decadal scale changes, year-to-year variations of the ozone VMR are observed that appear to be correlated with the quasi-biennial oscillation (QBO) of the equatorial wind (Baldwin et al., 2001).

Figure 1a shows that our CTM reproduces the overall amount and the year-to-year variability of the observed ozone very well, but fails to reproduce the decadal variability. The difference between the observed ozone during a given DJF period and that expected according to the CTM calculations shows a systematic behavior with little differences during solar maximum periods but negative anomalies of up to about 1 ppmv during the mid 1990s and the last three winters. These ozone anomalies - defined as the difference between modeled and observed ozone - are closely correlated with the flux of energetic electrons in the outer radiation belt measured by the GOES satellites at geostationary altitudes (Fig. 1c). The electron flux is closely related to the speed of the solar wind (Baker et al., 1987) and shows a clear 11year cycle with the maximum in the declining phase of the solar cycle. The electron data shown in Fig. 1c are averages 
over the period July to December; very similar results are obtained if slightly different averaging periods are chosen. This is partly due to the fact that the electron flux has a clear semi-annual cycle with minima around solstice and maxima around equinox (Baker et al., 1999) so that the inter-annual variability in the averaged electron flux is dominated by the variability around equinox.

According to our current understanding, precipitating electrons can produce large amounts of nitrogen oxides $\left(\mathrm{NO}_{\mathrm{x}}\right)$ and hydroxyl radicals $\left(\mathrm{HO}_{\mathrm{x}}\right)$ in the mesosphere through ionisation. In particular the short-lived $\mathrm{HO}_{\mathrm{x}}$ compounds destroy ozone very efficiently in the mesosphere, while the longer-lived $\mathrm{NO}_{\mathrm{x}}$ compounds can be transported downward into the stratosphere were they will lead to additional catalytic ozone loss. Increases of stratospheric $\mathrm{NO}_{\mathrm{x}}$ consistent with variations of the electron flux are indeed observed during winter and spring in the Antarctic stratosphere (Siskind et al., 2000). For the Arctic, however, the situation remains inconclusive, basically due to a lack of long-term measurements. Results from two coupled chemistry climate models have been reported very recently (Rozanov et al., 2005; Langematz et al., 2005) which show that stratospheric ozone can be affected significantly by enhanced $\mathrm{NO}_{\mathrm{x}}$ in the upper atmosphere due to energetic electron precipitation.

One of the open issue is how the GOES electron measurements are related to the flux of precipitating electrons into the atmosphere. The GOES electron measurements are not performed in the loss cone (e.g., Hess, 1968) and thus do not provide a direct measure of electron precipitation. It has been suggested that the auroral Ap-index (e.g., Siskind et al., 2000) may provide a better index for the effect of $\mathrm{NO}_{\mathrm{x}}$ enhancements due to electron precipitation. However, we find no correlation $(R=-0.2)$ between the ozone anomalies and the Ap-index averaged over July to December.

The negative ozone anomalies are first observed in the mid-stratosphere in autumn or early winter and subsequently propagate downward into the lower stratosphere during winter (Fig. 2a). Because our CTM calculations here do not include lower stratospheric ozone depletion due to chlorine activation on polar stratospheric clouds in winter and spring, these ozone depletions will appear here as well as negative anomalies in Fig. 2. From Fig. 2 there is some evidence that the downward propagating ozone anomalies may have contributed to the low ozone values in the lower stratosphere during spring in some years of the mid 1990s.

Similar features are observed also in Antarctic ozone measurements at Neumayer station (Fig. 2b) and South Pole (Fig. 2c). Significant negative ozone anomalies are observed at Neumayer predominantly during solar minimum, although the correlation with the electron flux is not as close as it is for the Arctic data at Ny-Ålesund. The negative anomalies are largely absent at South Pole; however, note the negative ozone anomaly observed at South Pole during winter/spring 2000 that has been attributed to the July 2000 solar proton event (Randall et al., 2001). There may be a number
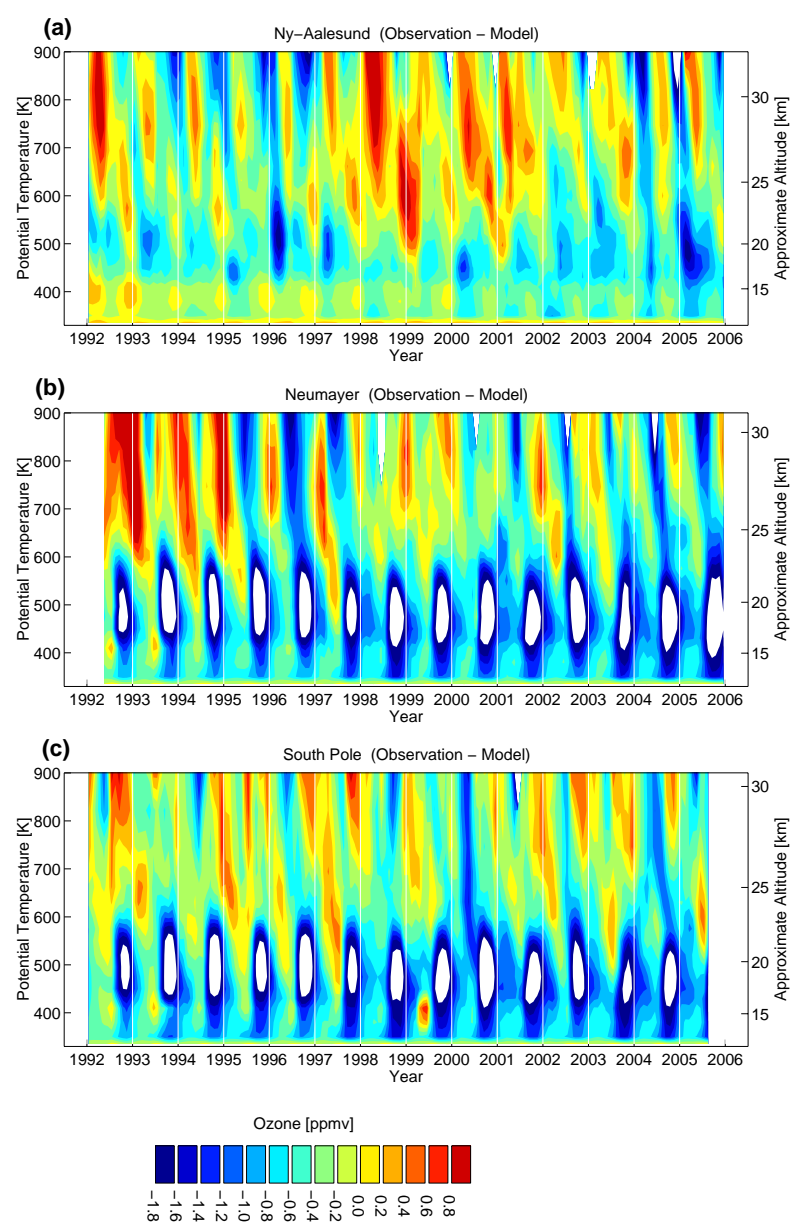

Fig. 2. Difference between modeled and measured ozone as a function of time and potential temperature. (a) Ny-Ålesund. (b) Neumayer. (c) South Pole. A three month running mean has been applied.

of reasons why the correlation of electron flux and ozone anomalies in the southern hemisphere is not as strong as it is in the northern hemisphere: (a) The relative locations of the magnetic poles and the meteorological conditions are different for the two hemispheres, (b) the three stations considered are at quite different latitudes, and (c) the precision of the ozone measurements is not as good in the southern hemisphere due to the smaller number of sonde measurements available during mid-winter, as is probably the quality of the meteorological analyses.

\subsection{Further evidence from SBUV observations}

The fact that the decadal scale ozone anomalies already appear in autumn before the onset of polar night gives us the chance to examine also measurements from the Solar Backscatter Ultra Violet (SBUV and SBUV/2) satellite instruments (e.g., Miller et al., 2002; Bhartia et al., 1996). SBUV(/2) data are available from 1979 onward and thus 


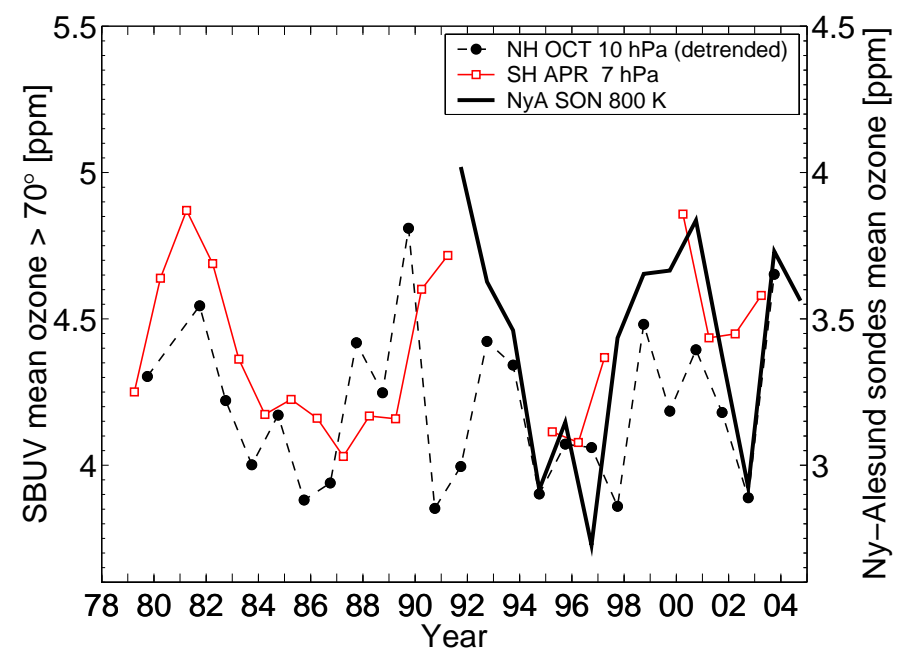

Fig. 3. Ozone north of $70^{\circ} \mathrm{N}$ during October (black dashed line with bullets) and south of $70^{\circ} \mathrm{S}$ during April (red solid line with squares) from SBUV measurements. Northern hemisphere SBUV data are detrended. Sonde measurements at $\mathrm{Ny}$-Ålesund, averaged over September, October, November, are shown for comparison (thick solid line).

cover two and a half solar cycles. However, as nadir looking solar backscatter instruments they cannot observe during polar night and due to drifts in the orbits of the satellites the high-latitude data coverage is rather poor during certain years. Figure 3 shows SBUV and SBUV/2 data averaged poleward of $70^{\circ}$ during October for the northern hemisphere and during April for the southern hemisphere. The data shown are Version 8 retrievals using SBUV on Nimbus-7 before 1990, SBUV/2 on NOAA-11 from 1990 to 1995 and from 1997 to 2000 , SBUV/2 on NOAA-9 for 1995 and 1996, and SBUV/2 on NOAA-16 after 2000. In order to get a reasonable coverage at high latitudes we had to include also measurements at solar zenith angles between $84^{\circ}$ and $88^{\circ}$ which are believed to have lower data quality. The northern hemisphere observations show a linear trend of $-0.3 \mathrm{ppm} / \mathrm{decade}$ which is removed from the data shown in Fig. 3. There is no such trend for the southern hemisphere observations; consequently the southern hemisphere data are not detrended. For comparison, Fig. 3 also shows the September to November mean ozone from sondes at NyÅlesund. Although the SBUV(/2) observations alone are at present probably not fully conclusive, they nevertheless provide additional support for the idea that: (a) there are decadal scale changes of ozone in the order of $1 \mathrm{ppm}$ between solar maximum and solar minimum, (b) these changes occur more or less simultaneously over both hemispheres and (c) they are not restricted to the period after 1990 but appear to be correlated with the solar activity over at least the last two and a half solar cycles.

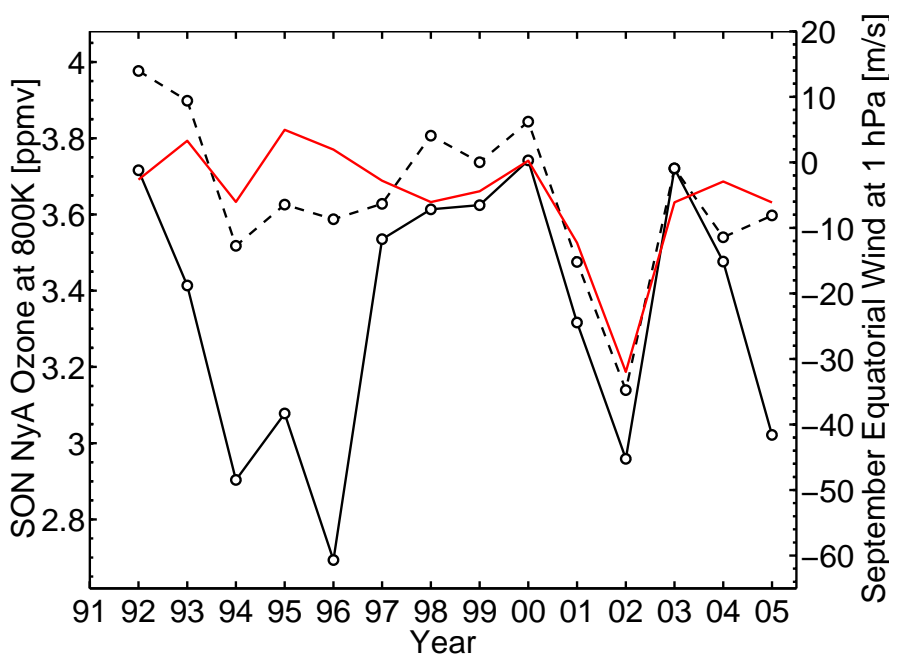

Fig. 4. Relation between upper stratospheric equatorial wind and mid-stratospheric Arctic ozone during autumn. September/October/November (SON) mean $800 \mathrm{~K}$ ozone at Ny-Åalesund from both observations (black solid line with symbols) and model (black dashed line with symbols) together with September mean zonal mean equatorial wind at $1 \mathrm{hPa}$ from UKMO analyses (red solid line).

\subsection{Relation to the upper stratospheric equatorial wind}

A number of studies have suggested that solar UV-induced variations in the equatorial upper stratosphere can have an indirect influence on the polar stratosphere in winter. For example, Gray et al. (2001) show that in addition to the well known relation between the quasi-biennial oscillation in lower stratospheric equatorial winds and polar temperatures (Holton and Tan, 1980) also the upper stratospheric autumnal equatorial wind at around $1 \mathrm{hPa}$ is strongly correlated with polar temperatures in winter. Kodera and Kuroda (2002) suggest that solar UV-induced changes in the low latitude upper stratosphere are transmitted to the high latitude polar stratosphere by influencing the internal mode of variation of the polar night jet and through changes in the Brewer-Dobson circulation.

In order to test whether the dynamical coupling with the equatorial upper stratosphere can serve as an alternative explanation for the decadal-scale ozone changes we searched for a correlation between mid-stratospheric ozone at Ny-Ålesund during autumn and early winter and the upper stratospheric equatorial wind. Figure 4 shows September/October/November (SON) mean $800 \mathrm{~K}$ ozone at NyÅalesund from both observations and model together with the September mean zonal mean equatorial wind at $1 \mathrm{hPa}$ from UKMO analyses. We find that part of the variation in modelled ozone can be explained by variations in the analysed equatorial wind, in particular the large anomaly in the year 2002. However, we don't find any correlation $(R<0.2)$ 
between measured ozone and the equatorial wind at $1 \mathrm{hPa}$. In particular the large decadal-scale changes in observed ozone can not be explained by anomalies in the equatorial wind. These findings are thus consistent with our hypothesis that there is an additional mechanism for reducing ozone during certain periods which is not included in our model and is probably related to electron precipitation. However, we cannot completely rule out the possibility that the decadal ozone variation is due to a dynamical response to solar UV-induced changes in the equatorial upper stratosphere not captured by the UKMO meteorological analyses and thus not present in modelled ozone from our CTM.

3.4 Impact on meteorology and possible climate implications

We find that the early winter ozone anomalies in the mid stratosphere at Ny-Ålesund are closely correlated with total ozone at Ny-Ålesund during the following March (Fig. 5a). The correlation is much weaker when modeled ozone is used instead of measured ozone. Similar results have very recently been found also in satellite measurements of Arctic ozone (Kawa et al., 2005). The observed correlation between early winter ozone in the middle stratosphere and total ozone during March is somewhat surprising, as it has been shown that the inter-annual variability of high latitude total ozone in March is largely controlled by the flux of atmospheric planetary scale waves into the stratosphere during mid-winter (Randel et al., 2002; Weber et al., 2003). In fact, we find for both hemispheres a close correlation between measured ozone in the mid-stratosphere during early winter and the flux of planetary waves into the stratosphere during mid-winter, expressed by the vertical component of the Eliassen-Palm (EP) flux at $100 \mathrm{hPa}$ during February (northern hemisphere, Fig. 5b) or August (southern hemisphere, Fig. 5c). The EP flux during mid winter largely controls polar stratospheric temperatures (Newman et al., 2001) and total ozone during late winter and spring. At present we can only speculate what causes the relation between early winter ozone and mid-winter EP flux. Following $\mathrm{Hu}$ and Tung (2003), a possible explanation could be as follows: A reduction of polar ozone may lead to an increased temperature contrast between mid- and high latitudes due to reduced radiative heating, modifying the refractive index for planetary waves and thereby suppressing the propagation of planetary waves into the stratosphere, which then could lead to further polar cooling and increased ozone loss.

\section{Conclusions}

Our finding of a large decadal scale variation in stratospheric ozone during winter suggests that solar variability exerts a larger influence on polar ozone than previously thought. Although we cannot give a complete explanation for the
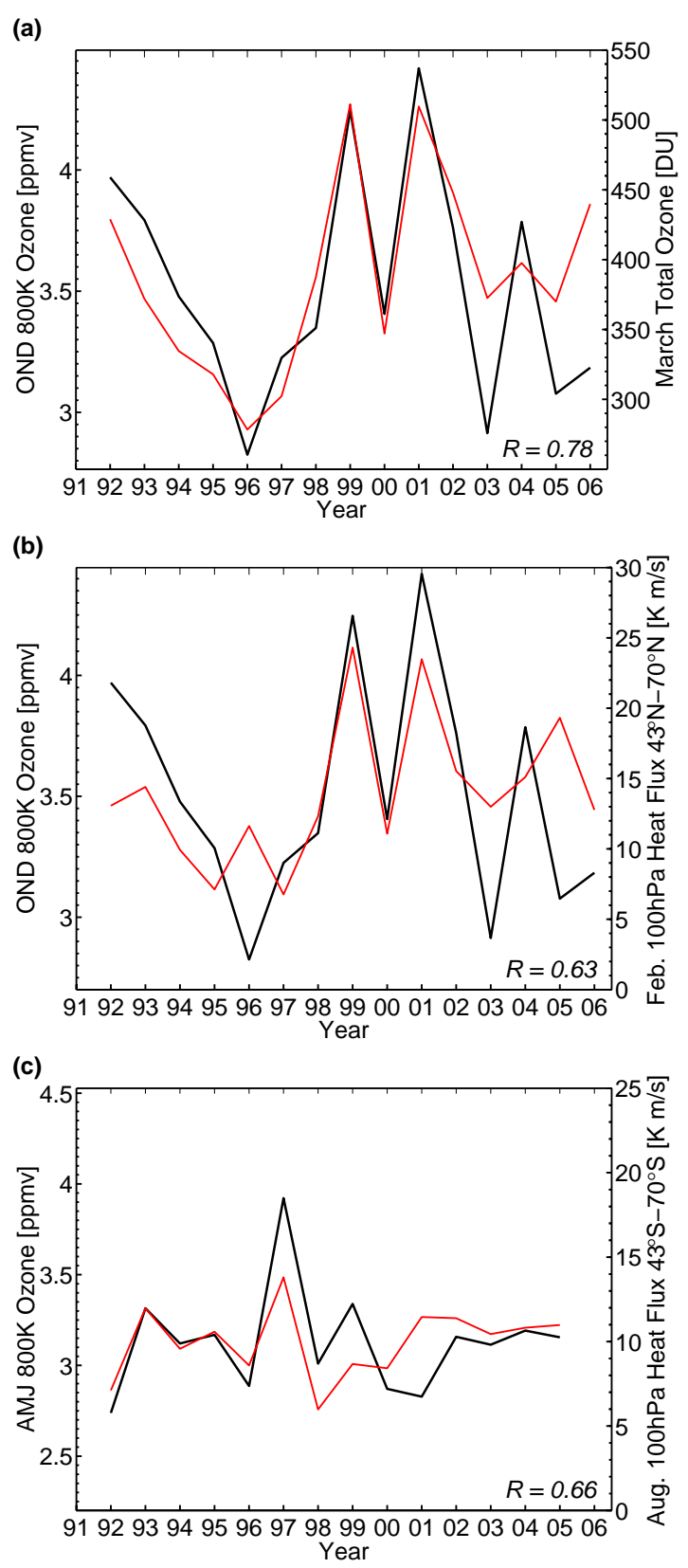

Fig. 5. Correlation of measured early winter ozone with total ozone and EP flux. (a) Measured October to December (OND) mean ozone at $800 \mathrm{~K}$ (black line), compared to measured March total ozone at Ny-Ålesund (red line). (b) Measured October to December (OND) $800 \mathrm{~K}$ mean ozone at Ny-Ålesund (black line), compared to February mean eddy heat flux at $100 \mathrm{hPa}$, averaged between $43^{\circ} \mathrm{N}$ and $70^{\circ} \mathrm{N}$ (red line). The eddy heat flux is proportional to the vertical component of the EP flux under quasi-geostrophic scaling (Newman et al., 2001). (c) Similar to panel (b), but for April to June (AMJ) mean ozone at South Pole, and August mean heat flux at $100 \mathrm{hPa}$, averaged between $43^{\circ} \mathrm{S}$ and $70^{\circ} \mathrm{S}$. Note that the sign of the eddy heat flux has been reverted in the southern hemisphere. 
observed decadal scale ozone changes, we propose precipitation of energetic electrons as a potential mechanism for the observed ozone changes. The close correlation of the difference between modeled and observed ozone with the flux of energetic electrons in the radiation belt supports this idea. However, it is currently not clear how the electron flux at geostationary altitude measured by the GOES satellites is related to the flux of energetic electrons precipitating into the atmosphere.

A direct effect of solar-UV changes can almost certainly be rouled out as a mechanism for the observed large decadal scale changes of polar ozone. There is some possibility that the high-latitude ozone changes are caused by solar-UV changes in the low latitude stratosphere through changes in atmospheric dynamics and transport. However, we did not find any evidence for such a mechanism.

Finally we note that if there is a direct link between early winter ozone and mid-winter EP flux, as suggested by the empirical correlation shown in Fig. 5, then the observed decadal scale changes in polar ozone could have a significant effect on polar stratospheric temperatures and climate.

Acknowledgements. The GOES electron flux measurements and the solar radio flux measurements were provided by the National Oceanic and Atmospheric Administration's National Geophysical Data Center. Meteorological analyses were provided by the UK Met Office via the British Atmospheric Data Centre. SBUV(/2) V8 data were taken from the DVD available from the National Oceanic and Atmospheric Administration's Climate Prediction Center. B.-M. Sinnhuber thanks M. Chipperfield and M. Weber for comments on an early version of the manuscript.

Edited by: M. Dameris

\section{References}

Baker, D. N., Blake, J. B., Gorney, D. J., Higbie, P. R., Klebesadel, R. W., and King, J. H.: Highly relativistic magnetospheric electrons: A role in coupling to the middle atmosphere?, Geophys. Res. Lett., 14, 1027-1030, 1987.

Baker, D. N., Kanekal, S. G., Pulkkinen, T. I., and Blake, J. B.: Equinoctial and solstitial averages of magnetospheric relativistic electrons: A strong semiannual modulation, Geophys. Res. Lett., 26, 3193-3196, 1999.

Baldwin, M. P., Gray, L. J., Dunkerton, T. J., et al.: The quasibiennial oscillation, Rev. Geophys., 39, 179-229, 2001.

Bhartia, P. K., McPeters, R. D., Mateer, C. L., Flynn, L. E., and Wellemeyer, C. G.: Algorithm for the estimation of vertical profiles from the backscattered ultraviolet technique, J. Geophys. Res., 101, 18 793-18 806, 1996.

Callis, L. B. and Lambeth, J. D.: $\mathrm{NO}_{\mathrm{y}}$ formed by precipitating electron events in 1991 and 1992: Descent into the stratosphere as observed by ISAMS, Geophys. Res. Lett., 25, 1875-1878, 1998.

Callis, L. B., Natarajan, M., and Lambeth, J. D.: Solar-atmospheric coupling by electrons (SOLACE) 3. Comparisons of simulations and observations, 1979-1997, issues and implications, J. Geophys. Res., 106, 7523-7539, 2001.
Callis, L. B., Natarajan, M., and Lambeth, J. D.: Reply to comment by D. E. Siskind on "Solar-atmospheric coupling by electrons (SOLACE), 3, Comparisons of simulations and observations" by Callis, L. B., Natarajan, M., Lambeth, J. D., et al., J. Geophys. Res., 107, 4634, doi:10.1029/2001JD001464, 2002.

Gray, L. J., Phipps, S. J., Dunkerton, T. J., Baldwin, M. P., Drysdale, E. F., and Allen, M. R.: A data study of the influence of the equatorial upper stratosphere on northern-hemisphere stratospheric sudden warmings, Q. J. R. Meteorol. Soc., 127, 19852003, 2001.

Haigh, J. D.: The role of stratospheric ozone in modulating the solar radiative forcing of climate, Nature, 370, 544-546, 1994.

Hess, W. N.: The Radiation Belt and Magnetosphere, Blaisdell Publishing Company, Waltham, Massachusetts, 1968.

Holton, J. R. and Tan, H.: The influence of the equatorial QuasiBiennial Oscillation on the global circulation at $50 \mathrm{mb}$, J. Atmos. Sci., 37, 2200-2208, 1980.

Hood, L. L.: Effects of solar UV variability on the stratosphere, in Solar Variability and Its Effects on Climate, edited by: Pap, J. and Fox, P., pp. 283-303, AGU, Washington, D.C., 2004.

$\mathrm{Hu}$, Y. and Tung, K. K.: Possible ozone-induced long-term changes in planetary wave activity in late winter, J. Clim., 16, 3027-3038, 2003.

Jackman, C. H., Fleming, E. L., and Vitt, F. M.: Influence of extremely large solar proton events in a changing stratosphere, J. Geophys. Res., 105, 11 659-11 670, 2000.

Kawa, S. R., Newman, P. A., Stolarski, R., and Bevilaqua, R. M.: Fall vortex ozone as a predictor of springtime total ozone at high northern latitudes, Atmos. Chem. Phys., 5, 1655-1663, 2005.

Kodera, K. and Kuroda, Y.: Dynamical response to the solar cycle, J. Geophys. Res., 107, 4749, doi:10.1029/2002JD002224, 2002.

Langematz, U., Grenfell, J. L., Matthes, K., Mieth, P., Kunze, M., Steil, B., and Brühl, Ch.: Chemical effects in 11-year solar cycle simulations with the Freie Universität Berlin Climate Middle Atmosphere Model with online chemistry (FUB-CMAM-CHEM), Geophys. Res. Lett., 32, L13803, doi:10.1029/2005GL022686, 2005.

McLinden, C. A., Olsen, S. C., Hannegan, B. J., Wild, O., Prather, M. J., and Sundet, J.: Stratospheric ozone in 3-D models: A simple chemistry and the cross-tropopause flux, J. Geophys. Res., 105, 14 653-14 665, 2000.

Miller, A. J., Nagatani, R. M., Flynn, L. E., et al.: A cohesive total ozone data set from the SBUV(/2) satellite system, J. Geophys. Res., 107, 4701, doi:10.1029/2001JD000853, 2002.

Newman, P. A., Nash, E. R., and Rosenfield, J. E.: What controls the temperature of the Arctic stratosphere during the spring?, J. Geophys. Res., 106, 19 999-20010, 2001.

Randall, C. E., Siskind, D. E., and Bevilacqua, R. M.: Stratospheric $\mathrm{NO}_{\mathrm{x}}$ enhancements in the Southern Hemisphere vortex in winter/spring of 2000, Geophys. Res. Lett., 28, 2385-2388, 2001.

Randall, C. E., Harvey, V. L., Manney, G. L., et al.: Stratospheric effects of energetic particle precipitation in 2003-2004, Geophys. Res. Lett., 32, L05802, doi:10.1029/2004GL022003, 2005.

Randel, W. J., Wu, F., and Stolarski, R.: Changes in column ozone correlated with the stratospheric EP flux, J. Meteorol. Soc. Japan, 80, 849-862, 2002.

Rozanov, E., Callis, L., Schlesinger, M., Yang, F., Andronova, N., and Zubov, V.: Atmospheric response to $\mathrm{NO}_{\mathrm{y}}$ source due to energetic electron precipitation, Geophys. Res. Lett., 32, L14811, 
doi:10.1029/2005GL023041, 2005.

Shindell, D., Rind, D., Balachandran, N., Lean, J., and Lonergan, P.: Solar cycle variability, ozone and climate, Science, 284, 305308, 1999.

Sinnhuber, B.-M., Weber, M., Amankwah, A., and Burrows, J. P.: Total ozone during the unusual Antarctic winter of 2002, Geophys. Res. Lett., 30, 1580, doi:10.1029/2002GL016798, 2003.

Siskind, D. E.: Comment on "Solar-atmospheric coupling by electrons (SOLACE), 3, Comparisons of simulations and observations" by Callis, L. B., Natarajan, M., Lambeth, J. D., et al., J. Geophys. Res., 107, 4633, doi:10.1029/2001JD001141, 2002.

Siskind, D. E., Nedoluha, G. E., Randall, C. E., Fromm, M., and Russell III, J. M.: An assessment of Southern Hemisphere stratospheric $\mathrm{NO}_{\mathrm{x}}$ enhancements due to transport from the upper atmosphere, Geophys. Res. Lett., 27, 329-332, 2000.
Smit, H. G. J. and Straeter, W.: Jülich Ozone Sonde Intercomparison Experiment 2000, World Meteorological Organization Global Atmosphere Watch - Report No. 158, Geneva, 2004.

Swinbank, R. and O'Neill, A.: A stratosphere-troposphere data assimilation system, Mon. Weather Rev., 122, 686-702, 1994.

Thorne, R. M.: Energetic radiation belt electron precipitation: A natural depletion mechanism for stratospheric ozone, Science, 197, 287-289, 1977.

Weber, M., Dohmse, S., Wittrock, F., Richter, A., Sinnhuber, B.M., and Burrows, J. P.: Dynamical control of $\mathrm{NH}$ and $\mathrm{SH}$ winter/spring total ozone from GOME observations 1995-2002, Geophys. Res. Lett., 30, 1583, doi:10.1029/2002GL016799, 2003.

World Meteorological Organization: Scientific Assessment of Ozone Depletion: 2002, Global Ozone Research and Monitoring Project - Report No. 47, Geneva, 2003. 